\title{
Toxic effects of cutaneous and oral exposure to aluminum and magnesium nanoparticles on brain tissue in rats
}

\author{
Zekeriya COŞAR ${ }^{1, a}$, Emre ARSLANBAŞ ${ }^{1, b, 凹}$ \\ ${ }^{1}$ Sivas Cumhuriyet University, Faculty of Veterinary Medicine, Pharmacology and Toxicology Department, Sivas, Turkey. \\ ${ }^{\mathrm{a} O R C I D: ~ 0000-0001-6323-446 X ; ~ ' ~} \mathrm{ORCID:}$ 0000-0003-0030-7195
}

Corresponding author: earslanbas @ cumhuriyet.edu.tr
Received date: 24.05.2019- Accepted date: 20.09.2019

\begin{abstract}
In this study, it was aimed to research the effects of cutaneous and oral exposure to aluminum nanoparticles (Al-NPs) and magnesium nanoparticles (Mg-NPs) on the brain tissue, which is vitally important in terms of its structure and functions. The study was performed on Wister-Albino rats, which were divided into 10 groups, such as control groups (groups 1 and 2), groups, to which $\mathrm{Al}$ and $\mathrm{Mg}$ NPs were applied as $500 \mathrm{mg} / \mathrm{kg}$ and $1500 \mathrm{mg} / \mathrm{kg}$ orally (groups 3-6) and $1000 \mathrm{mg} / \mathrm{kg}$ and $2000 \mathrm{mg} / \mathrm{kg}$ cutaneously (groups 7-10). The dosages were administered as a single dose. While brain tissue and serum MDA levels as well as brain tissue TNF- $\alpha$ and IL-6 levels have significantly increased in the group, to which $1500 \mathrm{mg} / \mathrm{kg} \mathrm{Mg-NPs}$ was applied orally, significant decreases have also been observed in brain tissue GPX and SOD levels of the same group. Additionally, meaningful decreases in brain tissue SOD levels and significant increases in TNF- $\alpha$ and IL-6 levels have been observed in the group, to which $1500 \mathrm{mg} / \mathrm{kg}$ Al-NP was applied orally. On the other hand, it was found that brain tissue GPX and SOD levels of the group, to which $2000 \mathrm{mg} / \mathrm{kg} \mathrm{Mg-NP}$ was applied cutaneous, have been decreased significantly. Histopathological examinations have also supported these findings. At the end of the study, it was observed that the toxic effect of $\mathrm{Al}$ and Mg NPs has varied, depending on the application method, dosage and duration.
\end{abstract}

Keywords: Aluminum nanoparticle, brain toxicity, cutaneous, magnesium nanoparticle, rat.

\section{Ratlarda deri ve ağız yoluyla alüminyum ve magnezyum nanopartiküllere maruziyetin beyin dokusu üzerindeki toksik etkileri}

Özet: Bu çalışmada, alüminyum nanopartiküllerine (Al-NP) ve magnezyum nanopartiküllerine (Mg-NP) önemli maruziyet yollarından olan deri ve ağız yoluyla maruziyetin, yapısı ve görevleri itibarıyla hayati öneme haiz beyin dokusu üzerindeki etkilerinin araştırılması amaçlandı. Çalışma; kontrol grupları (grup 1 ve 2), Al ve Mg NP'lerin $500 \mathrm{mg} / \mathrm{kg}$ ve $1500 \mathrm{mg} / \mathrm{kg}$ dozlarda ağız yoluyla (grup 3-6) ve $1000 \mathrm{mg} / \mathrm{kg}$ ve $2000 \mathrm{mg} / \mathrm{kg}$ dozlarda deri yoluyla (grup 7-10) verildiği gruplarda, tek doz uygulamalar yapılarak, 10 grup Wistar-Albino rat üzerinde gerçekleştirildi. Uygulama gruplarından Mg-NP'nin ağız yoluyla $1500 \mathrm{mg} / \mathrm{kg}$ dozda uygulandığı grupta beyin dokusu ve serum MDA düzeyleri ile beyin dokusu TNF- $\alpha$ ve IL-6 düzeyleri önemli ölçüde artarken, beyin dokusu GPX ve SOD düzeylerinde önemli azalmalar olduğu gözlendi. Ağız yoluyla Al-NP'nin $1500 \mathrm{mg} / \mathrm{kg}$ dozda verildiği grupta beyin dokusu SOD düzeylerinde anlamlı azalmalar ve TNF- $\alpha$ ve IL-6 düzeylerinde ise önemli artı̧̧lar tespit edildi. Diğer taraftan, deri yoluyla Mg-NP'nin $2000 \mathrm{mg} / \mathrm{kg}$ dozda verildiği grubun beyin dokusu GPX ve SOD düzeylerinde önemli bir azalma olduğu belirlendi. Histopatolojik incelemeler de bulguları destekledi. Çalışma sonucunda, $\mathrm{Al}$ ve Mg NP'lerin toksik etkisinin uygulama yoluna, verilen doza ve süreye bağli olarak değiştiği gözlendi.

Anahtar sözcükler: Alüminyum nanopartikül, beyin toksisitesi, deri, magnezyum nanopartikül, rat.

\section{Introduction}

As nanomaterials and nanoparticles (NPs) take more space in many areas of our lives, the number of products manufactured with nanotechnology does also increase day by day. The effectiveness and role of NPs in our lives have increased significantly in recent years since it has begun to be used widely in medicine, molecular biology and engineering, foodstuffs, cosmetics and other industries $(12,25,26)$. Various NPs being used in almost everywhere and in various forms have become promising for nanotechnology, but as their area of use increases their negative effects on the human health have also become a topic for debate (26).

Nanoparticles mainly enter the body through oral, respiration and cutaneous. Since they are small in sizes, a NP that has entered the body can easily penetrate into circulatory and lymph system and travel through all body tissues and organs. Some NPs may cause irreversible 
damages to cells, based on their composition and size (2, 5).

Nanoparticles affect basic cellular processes, such as proliferation, metabolism and death and many diseases can be associated with the dysfunction of these basic processes. For example, while neurodegenerative diseases are causing early death of cells, non-controllable cellular proliferations are causing cancer (5). Although it is not exactly known which mechanism are used by NPs to induce pro-inflammatory effects, it is asserted that they create reactive oxygen species (ROS) and induce cytokine production (3). Oxidative stress is responsible for cell and DNA damage (24). It is also accepted that severe inflammation is the first step of occurrence of systemic autoimmune diseases (systemic lupus erythematosus, scleroderma and rheumatic arthritis) as a result of being exposed to some NPs, such as silica and asbestos $(16,22)$.

Aluminum nanoparticles are used widely in various industries, such as ceramics, defence, dyeing and optics as well as in rocket fuels, food, implant, drug and vaccine production and in personal care products. People can be exposed to these particles either by consuming food and water or by using many other products that contain $\mathrm{Al}$ (23, 27). On the other hand, Mg-NPs are used to produce antimicrobial food packages, fire resistant ceramics, humidity sensors and syringes as well as in chemicals industry, surface coatings and fuel additives. They are also used as antacids against heartburn, detoxifying agents, for antibacterial purposes and bone regeneration $(8,10,14)$. Particularly magnesium oxide $(\mathrm{MgO})$ is a significant NP that attracts a lot of scientific attention due to its ease of synthesis and chemical stability properties and it does also have antibacterial activity. Its antibacterial effect is associated with the production of ROS on the oxide surface. On the other hand, it does also have an important cytotoxic effect; the studies showed its cytotoxic effects on human umbilical vein endothelial cells and cardiac microvascular endothelial cells and its toxicity on lung tissues $(8,14)$.

Nanoparticles have the potential to improve the environment and the lives of people, but their interaction with the environment is also inevitable. The results of using these particles are not completely defined yet for human health and the ecosystem. However, recent studies have revealed the toxic effects of NPs, to which humans are exposed through various means. Although the exposure to some NPs through respiration and oral has been found in a few studies that were made, the data are conflictive. On the other hand, NPs mainly enter the body through oral, respiration and cutaneous. In this study, it was aimed to research the effects of cutaneous and oral exposure to $\mathrm{Al}$ and $\mathrm{Mg} \mathrm{NPs}$ on the brain tissue, which is vitally important in terms of its structure and functions.

\section{Material and Methods}

Chemicals: Al-NPs $\left(\mathrm{Al}_{2} \mathrm{O}_{3}\right)<50 \mathrm{~nm}$ (Sigma Aldrich, 702129) and Mg-NPs (MgO) <50 nm (Sigma Aldrich, 549649 ) were used. $1 \mathrm{mg} / \mathrm{ml}$ concentration of the particles in distilled water was prepared in ultrasonic water bath and kept in sonicator for 2 hours before use. Polyethylene glycol (PEG) solution (Sigma Aldrich, P7181) was kept at $2-8^{\circ} \mathrm{C}$.

Experiment protocol: This study was performed with 80 adult male Wister-Albino rats, which were 6-9 months old and $230 \pm 20$ gr weight. All experiments were performed in Sivas Cumhuriyet University. Rats were kept under standard laboratory animal conditions (12 hours of light/dark cycle, $24 \pm 2^{\circ} \mathrm{C}, 35-60 \%$ humidity) and feed and water were given ad libitum. Experiments were made in accordance with the Guide on Caring and using Laboratory Animals (a publication of DHEW (NIH) 8523, 1985). The study was performed with the authorization (date: 04/03/2015, issue: 65202830/25) of Local Ethic Board of Animal Experiments of Sivas Cumhuriyet University (Turkey).

Rats were divided into 10 groups, each of which include 8 rats, such as control groups (groups 1 and 2), groups, to which $\mathrm{Al}$ and $\mathrm{Mg} \mathrm{NPs}$ were applied as 500 $\mathrm{mg} / \mathrm{kg}$ and $1500 \mathrm{mg} / \mathrm{kg}$ orally (groups 3-6) and 1000 $\mathrm{mg} / \mathrm{kg}$ and $2000 \mathrm{mg} / \mathrm{kg}$ cutaneously (groups 7-10) and these dosages were administered as a single dose $(18,19)$. The design of experimental groups were given in Table 1.

Table 1. Design of experimental groups.

\begin{tabular}{ll}
\hline Groups & Application \\
\hline Group 1 (Control group I) & PEG was applied through gavage to rats \\
Group 2 (Control group II) & PEG was applied cutaneous (through rubbing) to rats \\
Group $3(\mathrm{Al}$ NP-Oral-500) & $500 \mathrm{mg} / \mathrm{kg}$ dosage of Al-NPs was given within PEG to rats through gavage \\
Group 4 (Al NP-Oral-1500) & $1500 \mathrm{mg} / \mathrm{kg}$ dosage of Al-NPs was applied within PEG to rats through gavage \\
Group 5 (Mg NP-Oral-500) & $500 \mathrm{mg} / \mathrm{kg}$ dosage of Mg-NPs was given within PEG to rats through gavage \\
Group 6 (Mg NP-Oral-1500) & $1500 \mathrm{mg} / \mathrm{kg}$ dosage of Mg-NPs was applied within PEG to rats through gavage \\
Group 7 (Al NP-Cutan-1000) & $1000 \mathrm{mg} / \mathrm{kg}$ dosage of Al-NPs was given cutaneous (by rubbing) within PEG \\
Group 8 (Al NP-Cutan-2000) & $2000 \mathrm{mg} / \mathrm{kg}$ dosage of Al-NPs was given cutaneous (by rubbing) within PEG \\
Group 9 (Mg NP-Cutan-1000) & $1000 \mathrm{mg} / \mathrm{kg}$ dosage of Mg-NPs was applied cutaneous (by rubbing) within PEG \\
Group 10 (Mg NP-Cutan-2000) & $2000 \mathrm{mg} / \mathrm{kg}$ dosage of Mg-NPs was applied cutaneous (by rubbing) within PEG \\
\hline
\end{tabular}


Single dose of NPs was applied to the animals in all application groups. The hairs on $10 \%$ of the rat's body (dorsal area) were shaved before apply mentioned dosages of NPs cutaneous and it was ensured that applied NPs stayed for 24 hours on the same area. Then NPs were removed and animals were kept under observation for 14 and 28 days. The application was ended at the end of specified periods. When NPs were applied orally, the application was ended 14 and 28 days after NPs were given in specified dosages to the animals. Blood samples were taken from the anesthetized rats after experiments were completed. Subsequently, the brain tissues were removed carefully through necropsy and while some part of these brain tissues were being kept within 10\% formaldehyde solution for histopathological examinations, the remaining parts were kept at $-80^{\circ} \mathrm{C}$ in order for other analyses. The blood samples were centrifuged at $3000 \mathrm{rpm}$ for $15 \mathrm{~min}$ and sera were kept at $-80^{\circ} \mathrm{C}$ until further analyses.

Determination of lipid peroxidation: Lipid peroxidation was determined by malondialdehyde (MDA) content according to the method defined by Ohkawa et al. (20). MDA analyses were made in rat serum and brain tissue samples. MDA, a secondary product of lipid peroxidation was created by incubating with thiobarbituric acid (TBA) and sample at $100^{\circ} \mathrm{C}$ and in an aerobic environment, at where $\mathrm{pH}$ was 3.4 and lipid peroxidation was detected through spectrophotometer measurement of pink colour at $532 \mathrm{~nm}$, which was created in the form of a complex with MDA done TBA. Identified absorbance value was calculated as $\mathrm{nmol} / \mathrm{ml}$ from standard curve of MDA. The samples were read against the blind at $532 \mathrm{~nm}$ wavelength in spectrophotometer device (Perkin Elmer, Lambda 25 UV/VIS, USA).

Determination of glutathione peroxidase enzymes: Glutathione peroxidase (GPX) activity was determined with ELISA reader (Thermo Multiscan Go, USA) by using a commercially available standard enzymatic kit (YL Biont, YL Biotech Co, Shanghai). The ELISA kits, which are based on biotin double antibody sandwich technology, were used to detect rat GPX. Analyses were made according to the kit procedure, recommended by the manufacturer. The absorbance was read at $450 \mathrm{~nm}$.

Determination of superoxide dismutase enzyme: Superoxide dismutase (SOD) enzyme's activity was determined by ELISA reader in accordance with the procedure recommended by the manufacturer by using a standard enzymatic kit (Fn-test, Fine Biotech Co., China). According to this analysis procedure, kit plates, which were already coated with anti-SOD antibodies, and biotin conjugated anti-SOD antibodies were used as determination antibodies. TMB substrates were used to visualize the reaction of Horse Radish Peroxidase (HRP) enzyme. The absorbance was read at $450 \mathrm{~nm}$.
Determination of tumor necrosis factor alpha and interleukin 6: Tumor necrosis factor alpha (TNF- $\alpha$ ) and interleukin 6 (IL-6) levels were determined by using commercially available standard enzymatic kits (YL Biont, YL Biotech Co, Shanghai). The ELISA kits, which are based on biotin double antibody sandwich technology, were used to detect rat TNF- $\alpha$ and IL- 6 . Absorbance was read at $450 \mathrm{~nm}$.

Histopathological analysis: Rat brain tissue samples, which were kept in $10 \%$ formaldehyde solution for histopathological examinations, were embedded in paraffin and blocked after they were washed under tap water overnight and alcohol-xylol series were applied. Then $5 \mu \mathrm{m}$ of paraffin blocks were taken, placed on glass slide and stained with Haematoxylin-Eosin. Cornu ammonis (hippocampus) and Bulbus olfactorius regions of cross sections of all stained groups were examined under a light microscope (Zeiss AxioCam ERc5s, Germany) in order to evaluate and score inflammation, necrosis, gliosis, hyperaemia, oedema and demyelination.

Statistical analyses: The data were analysed by using SPSS (Version 23) software. The results were calculated as mean and standard error of mean (SEM). It was determined by Shapiro-Wilk whether the data were distributed normally or not. One way variance analysis (One-way ANOVA) and post hoc analysis Tukey test were used to find the difference between groups. The level of statistical significance was accepted as $\mathrm{P}<0.05$.

\section{Results}

Results of lipid peroxidation: When the brain tissue and serum MDA levels of groups, which orally received $500 \mathrm{mg} / \mathrm{kg}$ and $1500 \mathrm{mg} / \mathrm{kg}$ doses of $\mathrm{Al}$ and $\mathrm{Mg} \mathrm{NPs}$, were compared with control group (group 1), it was found that there was a statistically significant increase in group 6 according to control group $(\mathrm{P}<0.05)$. Brain tissue and serum MDA levels of experimental groups were given in Figure 1.

Glutathione peroxidase results: When brain tissue GPX levels of groups, to which $500 \mathrm{mg} / \mathrm{kg}$ and 1500 $\mathrm{mg} / \mathrm{kg}$ doses of $\mathrm{Al}$ and $\mathrm{Mg}$ NPs were given orally and control group (group 1), were compared, it was found that there was a statistically meaningful difference between the group 6 and control group $(\mathrm{P}<0.05)$. In addition, when brain tissue GPX levels of groups, to which $1000 \mathrm{mg} / \mathrm{kg}$ and $2000 \mathrm{mg} / \mathrm{kg}$ doses of $\mathrm{Al}$ and $\mathrm{Mg}$ NPs were given cutaneous and control group (group 2), were compared, it was found that there was a statistically significant decrease in group 10 compared to control group $(\mathrm{P}<0.05)$ (Figure 2).

Superoxide dismutase results: When brain tissue SOD levels of experimental groups, to which $500 \mathrm{mg} / \mathrm{kg}$ and $1500 \mathrm{mg} / \mathrm{kg}$ doses of $\mathrm{Al}$ and $\mathrm{Mg}$ NPs were given orally and control group (group 1), were compared, it was 
found that there was a statistically meaningful decrease in group 4 and group 6 according to control group $(\mathrm{P}<0.01)$. Furthermore, when brain tissue SOD levels of groups, which cutaneous received $1000 \mathrm{mg} / \mathrm{kg}$ and $2000 \mathrm{mg} / \mathrm{kg}$ doses of $\mathrm{Al}$ and $\mathrm{Mg}$ NPs, were compared with control group (group 2), it was found that there was a statistically meaningful difference between the group 10 and control group ( $\mathrm{P}<0.01)$. Brain tissue SOD levels of experimental groups were given in Figure 3.

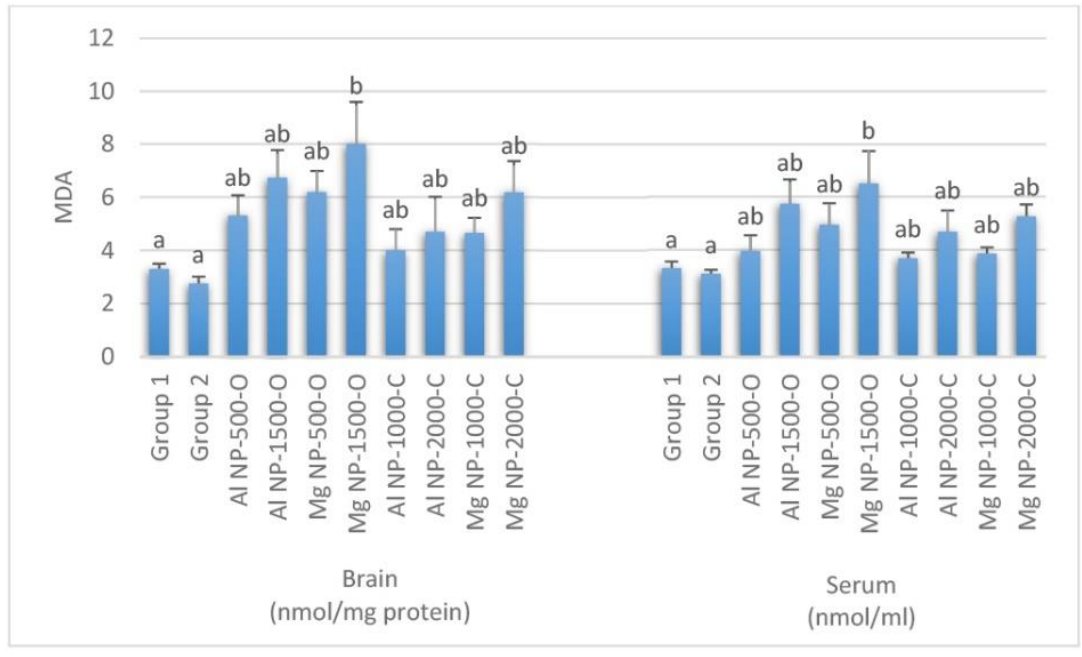

Different letters (a, b) identify the statistical difference between groups $(\mathrm{P}<0.05)$.

Figure 1. Brain tissue and serum MDA levels of experimental groups.

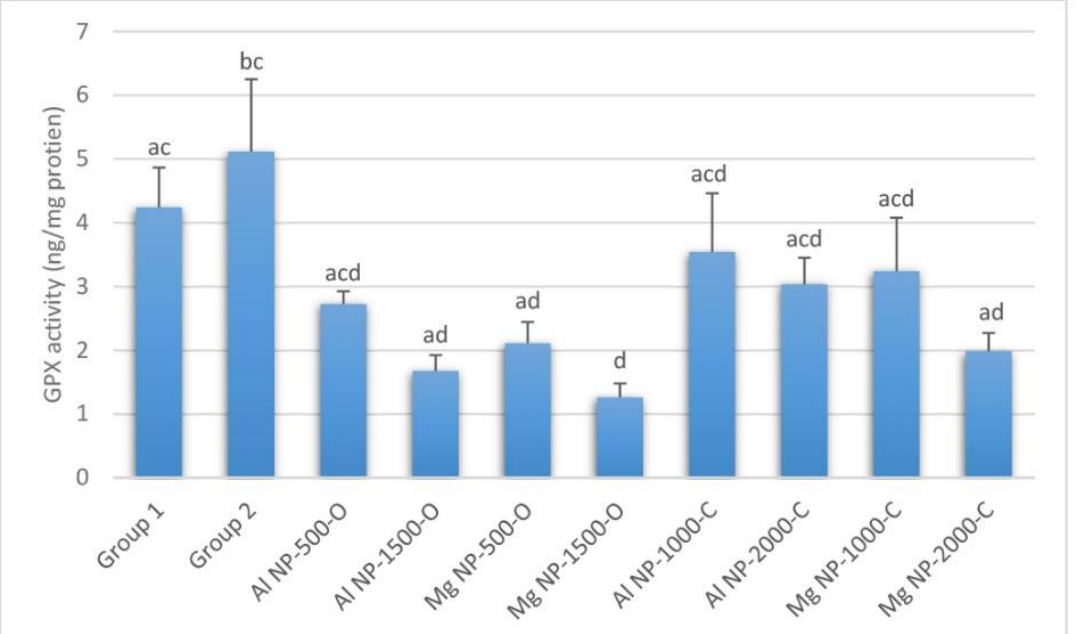

Different letters $(a, b, c, d)$ identify the statistical difference between groups $(\mathrm{P}<0.05)$.

Figure 2. Brain tissue GPX levels of experimental groups.

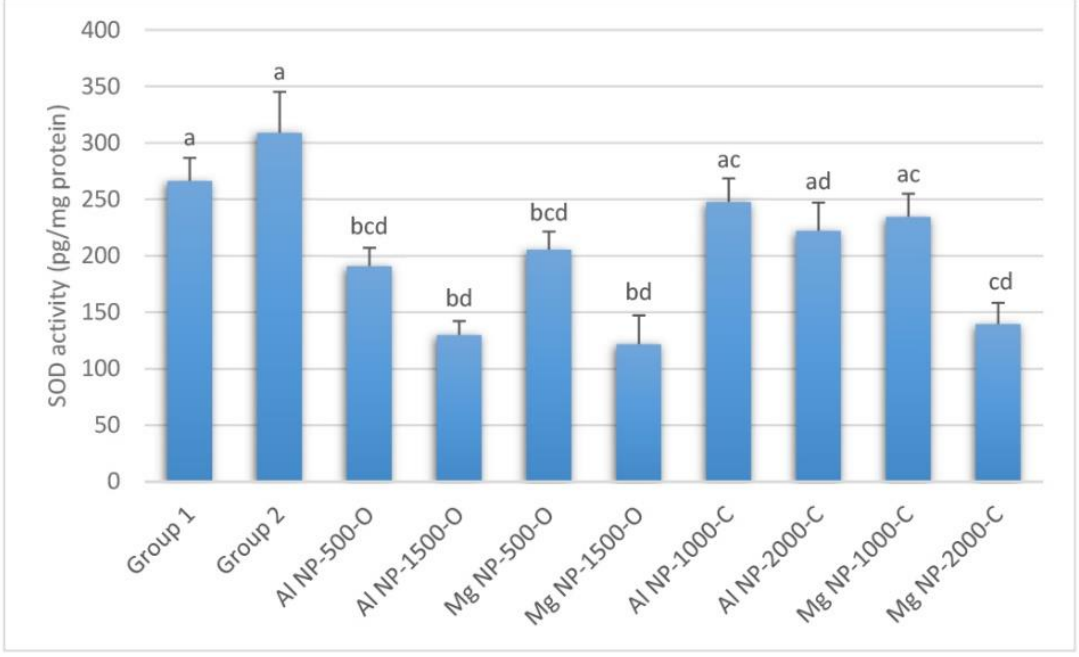

Different letters $(a, b, c, d)$ identify the statistical difference between groups $(\mathrm{P}<0.05)$.

Figure 3. Brain tissue SOD levels of experimental groups. 
Tumor necrosis factor alpha results: When brain tissue TNF- $\alpha$ levels of groups, to which $500 \mathrm{mg} / \mathrm{kg}$ and $1500 \mathrm{mg} / \mathrm{kg}$ doses of $\mathrm{Al}$ and Mg NPs were given orally and control group (group 1), were compared, it was found that there was a statistically meaningful increase in group 4 and group 6 compared to control group $(\mathrm{P}<0.05, \mathrm{P}<0.01)$ (Figure 4).

Interleukin 6 results: When brain tissue IL-6 levels of groups, which orally received $500 \mathrm{mg} / \mathrm{kg}$ and 1500 $\mathrm{mg} / \mathrm{kg}$ doses of $\mathrm{Al}$ and $\mathrm{Mg} \mathrm{NPs}$, were compared with control group (group 1), there was a significant increase in group 4 and group 6 according to control group $(\mathrm{P}<0.01)$ (Figure 5).

Histopathology results: Cross-sections taken from Cornu ammonis (hippocampus) and Bulbus olfactorius regions of brain tissue samples of experimental groups were examined in terms of inflammation, necrosis, gliosis, hyperaemia, oedema and demyelination and then histopathological changes were rated and summarized in Tables 2 and 3. No histopathological change was found in cross-sections, taken from samples of control groups (group 1 and 2). While slightly severe and mid-severe demyelination lesions were found in cross sections of Cornu ammonis (hippocampus) regions of group 5 and group 6, slightly severe inflammation was found in the group 10. Slightly severe inflammation was found in cross sections of Bulbus olfactorius regions of group 5 and group 10 (Figure 6).
Different letters (a, b, c, d) identify the statistical difference between groups $(\mathrm{P}<0.05)$.

Figure 4. Brain tissue TNF- $\alpha$ levels of experimental groups.
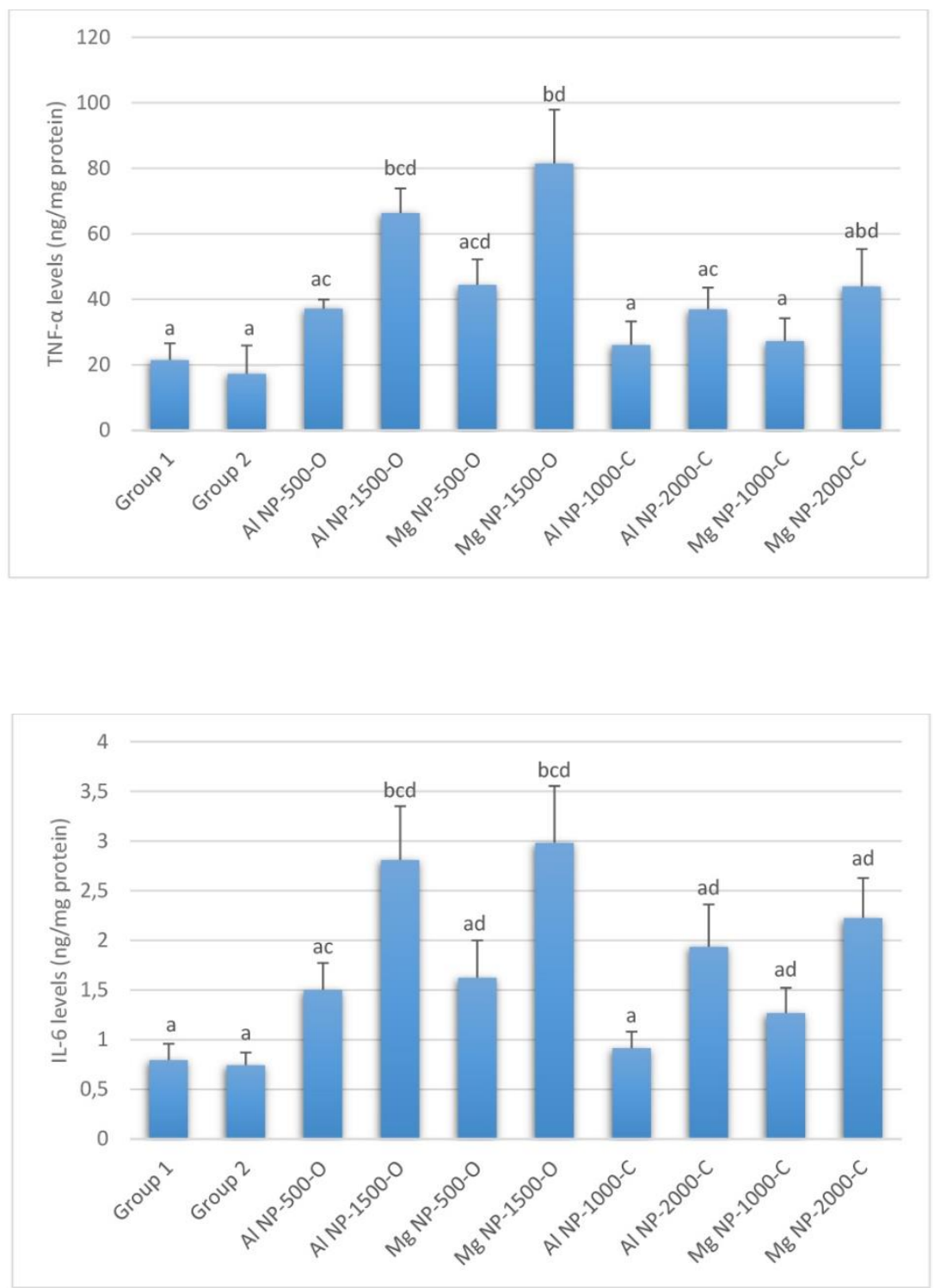

Different letters $(a, b, c, d)$ identify the statistical difference between groups $(\mathrm{P}<0.05)$.

Figure 5. Brain tissue IL-6 levels of experimental groups. 
Table 2. Scoring of histopathological features of cross sections, taken from brain tissue Cornu ammonis (hippocampus) regions of experimental groups.

\begin{tabular}{|l|c|c|c|c|c|c|}
\hline \multirow{2}{*}{ Groups } & \multicolumn{7}{|c|}{ Histopathological features } \\
\cline { 2 - 7 } & Inflammation & Necrosis & Gliosis & Hyperemia & Oedema & Demyelination \\
\hline Group 1 & - & - & - & - & - & - \\
\hline Group 2 & - & - & - & - & - & - \\
\hline Group 3 (Al NP-Oral-500) & - & - & - & - & - & - \\
\hline Group 4 (Al NP-Oral-1500) & - & - & - & + & - & - \\
\hline Group 5 (Mg NP-Oral-500) & - & - & - & ++ & - & + \\
\hline Group 6 (Mg NP-Oral-1500) & - & - & - & +++ & - & + \\
\hline Group 7 (Al NP-Cutan-1000) & - & - & - & + & - & - \\
\hline Group 8 (Al NP-Cutan-2000) & - & - & - & ++ & - & - \\
\hline Group 9 (Mg NP-Cutan-1000) & - & - & - & + & - & - \\
\hline Group 10 (Mg NP-Cutan-2000) & + & - & - & ++ & - & - \\
\hline$-:$ nyyyyyy
\end{tabular}

-: none; +: slightly severe; ++: mid-severe; +++: severe.

Table 3. Scoring of histopathological features of cross sections, taken from brain tissue Bulbus olfactorius regions of experimental groups.

\begin{tabular}{lcccccc}
\hline \multirow{2}{*}{ Groups } & \multicolumn{7}{c}{ Histopathological features } & Oedema & Demyelination \\
\cline { 2 - 6 } & Inflammation & Necrosis & Gliosis & Hyperemia & Oeder \\
Group 1 & - & - & - & - & - & - \\
Group 2 & - & - & - & - & - & - \\
Group 3 (Al NP-Oral-500) & - & - & - & - & - & - \\
Group 4 (Al NP-Oral-1500) & - & - & - & - & - \\
Group 5 (Mg NP-Oral-500) & + & - & - & - & - \\
Group 6 (Mg NP-Oral-1500) & - & - & - & - & - \\
Group 7 (Al NP-Cutan-1000) & - & - & - & - & - \\
Group 8 (Al NP-Cutan-2000) & - & - & - & - & - \\
Group 9 (Mg NP-Cutan-1000) & - & - & - & + & - & - \\
Group 10 (Mg NP-Cutan-2000) & + & - & - & - & - & - \\
\hline
\end{tabular}

-: none; +: slightly severe; ++: mid-severe.
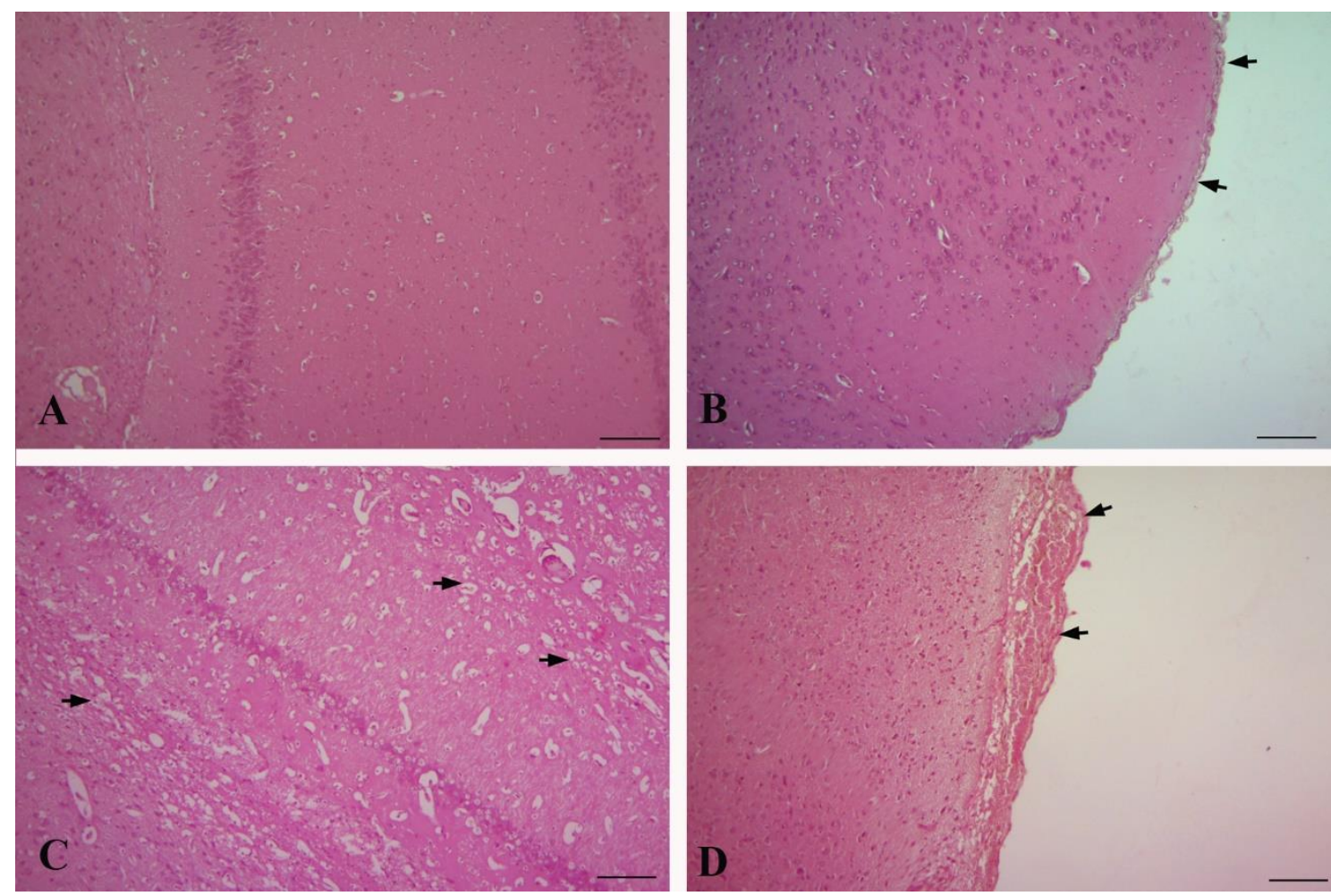

Figure 6. Photos of histopathological staining. A. Control groups of cross sections, taken from Cornu ammonis (hippocampus) regions, H\&E, Bar: $50 \mu \mathrm{m}$, B. Control groups of cross sections, taken from Bulbus olfactorius regions, H\&E, Bar: $50 \mu \mathrm{m}$, C. Slightly severe or mid-severe demyelination lesions in Cornu ammonis (hippocampus) (arrow), H\&E, Bar: $25 \mu \mathrm{m}$, D. Slightly to mid-severe Bulbus olfactorius hyperaemia and degeneration (arrow), H\&E, Bar: $50 \mu \mathrm{m}$. 


\section{Discussion and Conclusion}

When they are properly designed, NPs can show unique and adjustable chemical and physical characteristics and they may have unique biological effects in terms of developing technologies, but it is inevitable that they would interact with the environment. Furthermore, there is only limited literature about their effects on the health of humans, who are exposed to these particles through oral, cutaneous or respiration.

The special structure and vital tasks of brain tissue increase its sensitivity to NPs. It is rich in highly oxidizable poly-unsaturated fatty acids and has a high metabolic rate and weak antioxidant defence system. Therefore, reported to be particularly vulnerable to oxidative stress, and it is also stated that NPs have the ability to penetrate the blood-brain barrier (23).

It is stated that excessive $\mathrm{Al}$ dose is connected with some neurodegenerative diseases of humans, such as Alzheimer and Parkinson-dementia; it is also highlighted that it may cause adverse effects, such as inflammatory response or genetic damage, it may cause problems in ROS production and mitochondrial function disorders and it has carcinogenic potential and cytotoxic effects. The mitochondrial disorders and oxidative damages caused by $\mathrm{Al}$ on the neural cells lead to neural cells loss resulting in neurotoxic effect. On the other hand, Al does also affect antioxidant enzyme activity and causes oxidative damage. Furthermore, Al-NPs have a tendency to be accumulated in organs for various periods and in various quantities. The studies conducted on experimental animals showed that they are accumulated in all areas of brain after chronic exposure and they are found mostly in hippocampus, the area of memory and learning $(15,21)$. Mg-NPs may cause a decrease in antioxidant capacity and defence mechanisms, increase in ROS production and/or inhibition or depletion of antioxidant systems through mitochondrial dysfunction. Usually our bodies have a balance in production of free radicals and repairing of damage caused by these free radicals, but exposure to Mg-NPs impair this balance $(8,11)$.

In this study, increase in brain tissue oxidative stress parameters (MDA levels) and decrease in antioxidant potential (GPX, SOD levels) were found in group 4 and group 10, and particularly in group 6. Prabhakar et al. (23) investigated the effects of $\mathrm{Al}_{2} \mathrm{O}_{3}-\mathrm{NPs}$ administered by oral to rats (at doses of 500, 1000 and $2000 \mathrm{mg} / \mathrm{kg}$ ) on oxidative stress, which is accepted as an important mechanism in carcinogenesis. During the study the samples (liver, kidney, brain, heart) that were taken on the 3rd and 14th days were examined for oxidative stress parameters and it was found that MDA levels were meaningfully high, there was an increase in catalase (CAT) activity due to dosage, there was not any change in GPX and there was a decrease in glutathione (GSH), SOD and glutathione reductase (GR) activities. In another study, the effects of oxidative stress induced by $\mathrm{Al}$ on brain cortex neurons and glial cells were investigated and rats were administered $\mathrm{Al}$ at a dose of $100 \mathrm{mg} / \mathrm{kg}$ orally for 8 weeks. In experimental groups, a significant decrease was found in MDA, SOD, oxidized glutathione (GSSG), GPX, and CAT levels of glial cell fractions, increase in GSH, GR, glutathione-s-transferase (GST) levels, decrease in SOD, CAT, GSH, GSSG, GR, and GPX levels of neuronal cells and increase in MDA and GST levels (9). In a study, conducted by Mangalampalli et al. (14), in which they aimed to examine toxicological potential of $\mathrm{MgO}-\mathrm{NPs}$, they evaluated genotoxicity, histological, biochemical, antioxidant and bio-distribution parameters of blood and tissue (liver and kidney) samples, taken respectively 24 and 72 hours after application of low (100 $\mathrm{mg} / \mathrm{kg})$, medium $(500 \mathrm{mg} / \mathrm{kg})$ and high $(1000 \mathrm{mg} / \mathrm{kg})$ dosages of MgO-NPs orally to rats. As a result of the study, it was stated that acute exposure to high doses of $\mathrm{MgO}-\mathrm{NPs}$ causes significant DNA damage and biochemical changes, the antioxidant analyses (high MDA levels and SOD, CAT, GPX and total antioxidant depletion) have highlighted the oxidative stress and these results were supported with histopathological findings. Considering the findings such as brain tissue oxidative stress parameters (MDA levels), ROS generation, antioxidant potential (GPX and SOD levels) and effect do change at depending on the dose and duration in this study, it was found to be consistent with the results obtained in previous studies.

If an infection occurs, it activates chemical precursors that alert immunity system, such as proinflammatory mediators or intercellular cytokines (such as TNF- $\alpha$, IL-1 $\alpha$, IL-6) (4). Although it was not possible to completely explain induction mechanism of NPs for proinflammatory effects, it was asserted that they activate transcription factors, which modulate in-cell calcium concentration, they generate ROS and increase cytokine production (3). At the same time, it was highlighted that NPs can create ROS directly on their surfaces or through macrophage activation and cause an increase in production of oxidative types, antioxidant production and inflammation $(6,13,17)$.

It was found in the present study that brain tissue cytokine (TNF- $\alpha$, IL-6) levels were increased in group 4 and particularly in group 6. Park et al. (21) have examined toxic effects of $\mathrm{Al}_{2} \mathrm{O}_{3}-\mathrm{NPs}$, which was applied orally to mice for 13 weeks $(1.5,3$ and $6 \mathrm{mg} / \mathrm{kg}$ of doses; 6 times/week). When the results were compared with control group, an increase was observed in IL-6 levels, based on the amount of dosage. On the other hand, when the effects of NPs $\left(\mathrm{Al}_{2} \mathrm{O}_{3}, \mathrm{CeO}_{2}\right.$ and $\left.\mathrm{SiO}_{2}\right)$, which were used frequently in semiconductor industry, as a result of potential professional exposure were examined, it was 
found that $\mathrm{Al}_{2} \mathrm{O}_{3}-\mathrm{NPs}$ increases pro-inflammatory cytokine levels (TNF- $\alpha$, IL-6 and IL-1 $\beta$ ) (7). In the study conducted by Adamcakova-Dodd et al. (1) in order to examine toxic effects of $\mathrm{Al}_{2} \mathrm{O}_{3}$ based nanowhiskers, male mice were exposed to these nanomaterials for 2 or 4 weeks (4 hours/day and 5 days/week) in a dedicated exposure room. As a result, it was reported that no significant differences between control group and experimental groups were observed in terms of blood and bronchoalveolar lavage fluid LDH activity and cytokine levels (IL-6, IFN-y, MIP-la, TNF- $\alpha$ and MIP-2). The results of this study were found in conformity with the results of the studies, conducted by Park et al. (21) and Flaherty et al. (7) but not found in conformity with the results of the study, conducted by Adamcakova-Dodd et al. (1).

As a result of this study, it was found that brain tissue oxidative stress parameters (MDA levels) were increased, antioxidant potential (GPX, SOD levels) were decreased and cytokine (TNF- $\alpha$, IL-6) levels were increased in groups, to which $1500 \mathrm{mg} / \mathrm{kg}$ dose of Al-NPs was given orally (group 4) and $2000 \mathrm{mg} / \mathrm{kg}$ dose of Mg-NPs was given cutaneous (group 10), particularly including the group, to which $1500 \mathrm{mg} / \mathrm{kg}$ dose of Mg-NPs was given orally (group 6). Histopathological examinations have also supported these findings. It was observed that the toxic effect of $\mathrm{Al}$ and $\mathrm{Mg}$ NPs varies, depending on the application method, dosage and duration.

\section{Acknowledgements}

This work is supported by the Scientific Research Project Fund of Sivas Cumhuriyet University under the project number V-063 (CÜBAP, Sivas, Turkey). This study is summarized from the first author's master thesis entitled "Investigation of the Effects of Brain Tissue Through the Skin and Oral Aluminum and Magnesium Nanoparticles Exposure in Rats".

\section{Conflict of Interest}

The authors declared that there is no conflict of interest.

\section{References}

1. Adamcakova-Dodd A, Stebounova LV, O'Shaughnessy PT, et al (2012): Murine pulmonary responses after subchronic exposure to aluminum oxide-based nanowhiskers. Part Fibre Toxicol, 9, 22-36.

2. Borm PJA, Robbins D, Haubold S, et al (2006): The potential risks of nanomaterials: A review carried out for ECETOC. Part Fibre Toxicol, 3, 11-46.

3. Brown DM, Donaldson K, Borm PJ, et al (2004): Calcium and ROS-mediated activation of transcription factors and $T N F$ - $\alpha$ cytokine gene expression in macrophages exposed to ultrafine particles. Am J Physiol Lung Cell Mol Physiol, 286, 344-353.
4. Brown DM, Donaldson K, Stone V (2004): Effects of PM10 in human peripheral blood monocytes and J774 macrophages. Respir Res, 5, 29-41.

5. Buzea C, Blandino IIP, Robbie K (2007): Nanomaterials and nanoparticles: Sources and toxicity. Biointerphases, $\mathbf{2}$, 17-172.

6. Donaldson K, Stone V (2003): Current hypotheses on the mechanisms of toxicity of ultrafine particles. Ann 1st Super Sanita, 39, 405-410.

7. Flaherty NL, Chandrasekaran A, Peña MPS, et al (2015): Comparative analysis of redox and inflammatory properties of pristine nanomaterials and commonly used semiconductor manufacturing nano-abrasives. Toxicol Lett, 239, 205-215.

8. Gelli K, Porika M, Anreddy RNR (2015): Assessment of pulmonary toxicity of $\mathrm{MgO}$ nanoparticles in rats. Environ Toxicol, 30, 308-314.

9. Khanna P, Nehru B (2007): Antioxidant enzymatic system in neuronal and glial cells enriched fractions of rat brain after aluminum exposure. Cell Mol Neurobiol, 27, 959-969.

10. Khanooki TA, Fazilati M (2014): The toxicity effect of magnesium oxide nanoparticles. Adv Environ Biol, 8, 969973.

11. Kiranmai G, Reddy ARN (2012): Antioxidant status in $\mathrm{MgO}$ nanoparticle-exposed rats. Toxicol Ind Health, 29, 897-903.

12. Koç F, Baydan E (2003): Nanopartiküller. Erc Üniv Sağ Bil Derg, 12, 65-69.

13. Long H, Shi T, Borm PJ, et al (2004): ROS-mediated TNF$\alpha$ and MIP-2 gene expression in alveolar macrophages exposed to pine dust. Part Fibre Toxicol, 1, 3-11.

14. Mangalampalli B, Dumala N, Grover P (2017): Acute oral toxicity study of magnesium oxide nanoparticles and microparticles in female albino wistar rats. Regul Toxicol Pharmacol, 90, 170-184.

15. Mirshafa A, Nazari M, Jahani D, et al (2018): Sizedependent neurotoxicity of aluminum oxide particles: A comparison between nano- and micrometer size on the basis of mitochondrial oxidative damage. Biol Trace Elem Res, 183, 261-269.

16. Noonan CW, Pfau JC, Larson TC, et al (2006): Nested case-control study of autoimmune disease in an asbestosexposed population. Environ Health Perspect, 114, 12431247.

17. Oberdörster G, Oberdörster E, Oberdörster J (2005): Nanotoxicology: An emerging discipline evolving from studies of ultrafine particles. Environ Health Perspect, 113, 823-839.

18. Organisation for Economic Cooperation and Development (OECD) (1987): Acute dermal toxicity. OECD Guideline for testing of chemicals, Test No 402, 24 Feb 1987.

19. OECD-Organisation for Economic Cooperation and Development (2001): Acute oral toxicity-Acute toxic class method. OECD Guideline for testing of chemicals, Test No 423, 17 December 2001.

20. Ohkawa H, Ohishi N, Yagi K (1979): Assay for lipid peroxides in animal tissues by thiobarbituric acid reaction. Anal Biochem, 95, 351-358. 
21. Park EJ, Sim J, Kim Y, et al (2015): A 13-week repeateddose oral toxicity and bioaccumulation of aluminum oxide nanoparticles in mice. Arch Toxicol, 89, 371-379.

22. Pfau JC, Sentissi JJ, Weller G, et al (2005): Assessment of autoimmune responses associated with asbestos exposure in Libby, Montana, USA. Environ Health Perspect, 113, 2530.

23. Prabhakar PV, Reddy UA, Singh SP, et al (2012): Oxidative stress induced by aluminum oxide nanomaterials after acute oral treatment in wistar rats. J Appl Toxicol, 32, 436-445.
24. Risom L, Møller P, Loft S (2005): Oxidative stressinduced DNA damage by particulate air pollution. Mutat Res, 592, 119-137.

25. Roco MC (2005): International perspective on government nanotechnology funding in 2005. J Nanopart Res, 7, 707712.

26. Shim KH, Hulme J, Maeng EH, et al (2014): Analysis of zinc oxide nanoparticles binding proteins in rat blood and brain homogenate. Int J Nanomedicine, 9, 217-224.

27. Yang ST, Wang T, Dong E, et al (2012): Bioavailability and preliminary toxicity evaluations of alumina nanoparticles in vivo after oral exposure. Toxicol Res, $\mathbf{1}$, 69-74. 